\title{
Following a Dangerous Precedent: The California Rule and the Kansas Pension Crisis
}

\author{
Phillip Moderson*
}

I. INTRODUCTION

Imagine a remote town in need of water. The townspeople determine a reservoir is necessary to supply the water required to maintain their normal way of life. The town builds a dam, diverts a river, and as a result, creates a reservoir. However, imagine now that the town designed the dam poorly. Leaks sporadically burst open across the dam's foundation, gushing water at an alarming rate. Rather than fix the dam, the town diverts another river to the reservoir. The leaks in the dam now produce a steady stream, and the reservoir's water level continues to lower. The town grows increasingly desperate and diverts yet another river to the reservoir. The reservoir's water level continues to lower though, and in an endless cycle of attempts to remedy the problem, the town stubbornly diverts more rivers to the reservoir. The more logical solution to the problem would be to ascertain the design flaws in the dam and fix the leaks. By avoiding the true problem - the faulty dam - the town wasted vital resources and endangered its future sustainability. Although the town's reasoning may seem absurd, the illustration accurately depicts the Kansas pension crisis and the flawed rationale that Kansas pension law promotes.

The hypothetical dam is the Kansas Public Employees Retirement System (KPERS), which oversees the largest pension fund in the state of Kansas. ${ }^{1}$ KPERS is responsible for the retirement plans of over 289,000 state and local government employees and manages approximately $\$ 16$

\footnotetext{
* J.D. Candidate, 2017, University of Kansas School of Law; B.S., 2014, University of Kansas. Thank you to Ashley Akers, Professor Harper Ho, and the members of Kansas Law Review for providing consistent guidance and support.

1. Gene Meyer, Kansas Boosts Pension Funding Now to Save Money Later, The HeARTLAND INST., http://news.heartland.org/newspaper-article/kansas-boosts-pension-funding-now-save-moneylater (last visited Mar. 24, 2016).
} 
billion in assets. ${ }^{2}$ The funds KPERS manages, similar to the hypothetical reservoir, are intended to provide employees with the means to sustain a normal lifestyle beyond retirement.

KPERS affects more than retirees, though. In fact, KPERS impacts almost every aspect of Kansas's infrastructure. The reach of KPERS is expansive, covering nearly 300 school districts, over 400 cities and townships, and more than 1,500 employers. ${ }^{3}$ Kansas's teachers, police officers, firefighters, judges, and many others that currently serve as the backbone of the state and municipal systems rely on KPERS pension plans to safeguard their futures. ${ }^{4}$ In total, approximately $10 \%$ of all Kansas residents are members of a KPERS pension plan. ${ }^{5}$

Beyond the clear importance of KPERS to the citizens of Kansas, there is an imminent problem lurking: KPERS is dangerously underfunded. Kansas's pension funding is below $60 \%$ of what will be due to future retirees, ${ }^{6}$ falling $20 \%$ short of the minimum amount needed to achieve a healthy pension fund. ${ }^{7}$ In total, KPERS has a $\$ 9.5$ billion gap between state revenue and benefits owed to pension members. ${ }^{8}$

KPERS has struggled with excessive liabilities for more than a decade, ${ }^{9}$ but Kansas pension law has been a consistent barrier preventing the legislature from properly addressing one of the key sources of the pension deficit: imperfectly designed KPERS plans. The plans rely on high investment returns and underestimated lifespans of retirees. ${ }^{10}$ The

2. About Us, KPERS, http://www.kpers.org/about/home.html (last visited Mar. 24, 2016) [hereinafter About Us, KPERS].

3. Alan D. Conroy, Exec. Dir., KPERS, Presentation materials from KPERS Legislative Update to the House Pensions and Benefits Committee, at 3 (Jan. 13, 2014), http://kslegislature.org/li_2014/b2013_14/committees/ctte_h_pen_ben_1/documents/testimony/2014 0113_01.pdf.

4. See About Us, KPERS, supra note 2 .

5. Conroy, supra note 3, at 3 .

6. See id. at 7.

7. See Public Pension Health by State, BAllotPEDIA, http://ballotpedia.org/Public_pension_health_by_state (last visited Mar. 24, 2016) (“According to the Pew Center, in order for a state to have what is considered a fiscally sustainable pension plan, that plan must have a funded ratio of at least 80 percent.").

8. Frank Shafroth, Kansas's March to Zero, TAX ANALYSTS (2015), reprinted in STATE TAX TODAY, 2015 STT 179-7 (2015).

9. Benefit Changes Coming for KPERS Members, BENEFITWise NeWSLETTER (Kan. Pub.

Emps. Ret. Sys., Topeka, Kan.), Sept. 2013, at 1, 2, http://www.kpers.org/newsletters/pdf/benefitwise2013vol2_State.pdf [hereinafter BENEFITWISE NEWSLETTER].

10. See John Hanna, Report Says KPERS Needs Overhaul to Remain Solvent, LAWRENCE J.WORLD (Sept. 23, 2009, 7:59 PM), http://www2.ljworld.com/news/2009/sep/23/report-says-kpersneeds-overhaul-remain-solvent/ (showing that Kansas utilizes pension techniques that overvalue 
plans also allow government officials to guarantee retirement benefits up front and then simply let future officials assume the burden of delivering on the benefits. ${ }^{11}$

The ability to correct the pension plans is severely hampered by the Kansas Supreme Court's decision in 1980 to adopt California pension law (the California Rule). ${ }^{12}$ The California Rule prohibits modifications that reduce employee benefits unless the modifications are accompanied by comparable advantages. ${ }^{13}$ In application, the rule ensures that employees will continue to earn benefits at least as generous as once promised by the state. ${ }^{14}$ In other words, the rule permits unilateral decreases in employee contribution rates, increases in employee benefits, and a wide variety of other modifications that are viewed as beneficial to KPERS members. ${ }^{15}$ Conversely, there can be no increases in employee contribution rates, reductions in future benefits, or any other type of modification unfavorably affecting KPERS members unless the modifications are also accompanied by equivalent and offsetting advantages for KPERS members. ${ }^{16}$ As a result, the California Rule substantially limits the Kansas legislature's ability to appropriately address pension liabilities.

The Kansas legislature is growing increasingly active in its efforts to remedy the pension crisis. Kansas plans to issue $\$ 1$ billion worth of bonds to alleviate pension liabilities. ${ }^{17}$ Furthermore, modifications to

\footnotetext{
assets and project investment returns at an average of $8 \%$ per year); see Timothy W. Martin, Public Pension Funds Roll Back Return Targets, WALL ST. J. (Sept. 4, 2014), http://www.wsj.com/articles/taxpayers-more-pension-burdens-headed-your-way-1441388090 (illustrating the danger of relying on high investment projections, a decrease of only $1 \%$ on an investment return rate will typically increase pension liabilities by $12 \%$ ); Scott Rothschild, KPERS Studies Increase in Retirement Age, LAWrENCE J.-WORLD (July 25, 2006), http://www2.ljworld.com/news/2006/jul/25/kpers_studies_increase_retirement_age/?politics (stating a previous KPERS executive director's opinion that the pension system is ill-equipped to handle longer lifespans of employees and that the minimum KPERS retirement age should be increased from 55 to 65); BENEFITWISE NeWSLETTER, supra note 9, at 2 (citing investment losses, longer member lifespans, and early employee retirements as partial causes of the pension shortfall).

11. Hanna, supra note 10 ("[T] he current system allows state officials to promise good benefits now and let future officials worry about how to pay for them.").

12. See Singer v. City of Topeka, 607 P.2d 467, 475-76 (Kan. 1980) (adopting the rule outlined in Allen v. City of Long Beach, 287 P.2d 765 (Cal. 1955)).

13. See id. at 476.

14. Alexander Volokh, Overprotecting Public Employee Pensions: The Contract Clause and the California Rule, THE FEDERALIST SOC'Y 6 (July 2014),

http://reason.org/files/overprotecting_pensions_california_rule.pdf.

15. See id. at 6-7.

16. Id.

17. Tim Carpenter, Governor Signs $\$ 1 B$ Bonding Bill for KPERS, TOPEKA CAP. J. (Apr. 16,
} 
pension plans are at the forefront of the legislature's options to decrease pension liabilities. ${ }^{18}$ The impending pension crisis and pension modifications carry ramifications for employers, employees, and the entire state of Kansas. Pension modifications also create legal questions regarding state employees' rights to their dwindling pension funds and the Kansas legislature's ability to restructure current pension plans without violating those rights.

However, Kansas is not alone in addressing pension liabilities. In 2014 , state pension plans in the United States were underfunded by $\$ 4.7$ trillion. ${ }^{19}$ Pension plans of twenty-six states have a funding ratio of less than $70 \%$ of pension liabilities. ${ }^{20}$ Accordingly, several state legislatures have attempted to reduce pension liabilities by modifying state pension plans. The United States Supreme Court and the Colorado Supreme Court have recently addressed the legality of pension modifications, and in doing so, have provided an alternative path for the Kansas Supreme Court to potentially follow. ${ }^{21}$ The pension crisis and impending legislation provide the Kansas Supreme Court with a pivotal opportunity to learn from similarly situated courts and correct the legal precedent that has failed the Kansas retirement system.

This Comment will navigate the ambiguous areas of Kansas pension law, clarify KPERS members' potential claims, and provide a simple solution that creates a less restrictive precedent. Part II will provide a general overview of KPERS, Kansas pension regulations, and the origin of Kansas's precedent on the matter. Part III will provide a detailed illustration of when KPERS members have potential claims, examine the policy purposes underlying the California Rule, illustrate the California Rule's failure to fulfill its policy purposes, and explain how the United States Supreme Court's recent pension analysis in M\&G Polymers USA, LLC v. Tackett ${ }^{22}$ refutes the legal concepts that form the foundation of the California Rule. Part IV will recommend that the Kansas Supreme

\footnotetext{
2015, 6:10 PM), http://cjonline.com/news/state/2015-04-16/governor-signs-1b-bonding-bill-kpers.

18. See Conroy, supra note 3, at 16-20.

19. Joe Luppino-Esposito, Promises Made, Promises Broken 2014: Unfunded Liabilities Hit $\$ 4.7$ Trillion, STATE BudGET SOLS. (Nov. 12, 2014),

http://www.statebudgetsolutions.org/publications/detail/promises-made-promises-broken-2014unfunded-liabilities-hit-47-trillion.

20. Robert Hennelly, States are Staring at a Trillion-Dollar Pension Hole, CBS NEws (July 31, 2015, 6:00 AM), http://www.cbsnews.com/news/states-are-staring-at-a-1-trillion-pension-hole/.

21. Justus v. State, 336 P.3d 202 (Colo. 2014); M\&G Polymers USA, LLC v. Tackett, 135 S. Ct. 926 (2015).

22. $M \& G$ Polymers, 135 S. Ct. 926 (2015).
} 
Court abandon the California Rule and discontinue its treatment of statutorily defined pension plans as contracts. Part V will conclude with a summary of the proper outcome to the pension crisis.

\section{BACKGROUND}

This section will first address the background of KPERS, the Kansas legislature's previous attempts to remedy the pension crisis, and the characteristics of a KPERS retirement plan. Second, this section will clarify how Kansas law differentiates between retroactive modifications to pension plans and prospective modifications to pension plans.

\section{A. Background of KPERS}

The Kansas legislature created the first KPERS plan in 1961 and offered it to state and local employees. ${ }^{23}$ Over the next several decades, the plan grew to encompass a variety of state employers and employees. ${ }^{24}$ KPERS currently administers three pension plans: a police and firefighters plan, a judges and justices plan, and the largest pension plan, known as "regular KPERS." 25 Regular KPERS includes state, school, and local employees. ${ }^{26}$ Its vast coverage constitutes $95 \%$ of KPERS active membership and is separated into three tiers. ${ }^{27}$ The factors that led to the creation of the current KPERS three-tier system illustrates the flawed logic that the California Rule promotes and the legislature's inability to properly respond to the causes of the Kansas pension deficit.

In order to fully understand the current KPERS system, the circumstances leading to pension deficit must be explored. The economic downturn in 2008 harmed Kansas's pension funding, but it does not explain the entirety of the problem. ${ }^{28}$ Benefit increases for members, low contributions, longer member lifespans, earlier member retirement rates, and economic downturns have all contributed to

\footnotetext{
23. Julian Efird \& Michael Steiner, Review of KPERS History for the House Committee on Pension and Benefits, KAN. Legislative Research DeP'T 1 (Jan. 30, 2013), http://www.kslegislature.org/li_2014/b2013_14/committees/misc/ctte_h_pen_ben_1_20130130_03_ other.pdf.

24. Id. at $1-2$.

25. Id. at 1 .

26. Id.

27. Conroy, supra note 3 , at 4 .

28. See BENEFITWISE NEWSLETTER, supra note 9, at 2.
} 
Kansas's pension deficit. ${ }^{29}$

The legislature has struggled with excessive KPERS liabilities for more than a decade, ${ }^{30}$ but it has remained unable to deliver a sustainable solution to the problem. In 2003, the legislature authorized the issuance of up to $\$ 500$ million of pension obligation bonds. ${ }^{31}$ However, the bonds only served as a temporary solution. ${ }^{32}$ The legislature eventually closed the original retirement plan to new members, preventing all future government employees from joining. ${ }^{33}$

The original plan is now labeled tier one, and the Kansas legislature created a KPERS second-tier plan in 2007 for new members unable to join the original plan. $^{34}$ Accordingly, any state, school, or local employees becoming members after 2009 had to join the tier-two plan. ${ }^{35}$ The tier-two plan was similar to tier one, but it contained modifications aimed at increasing payment responsibility for the employers and employees. ${ }^{36}$ For example, a tier-one employee contributed $4 \%$ of his or her salary to the pension plan, but a tier-two employee was forced to contribute $6 \% .{ }^{37}$ However, the addition of tier two did little to resolve the problem of increasing pension liabilities, and in January 2015, legislation came into effect that essentially closed tier-two plans from covering additional members. ${ }^{38}$

New members are now part of tier-three plans. ${ }^{39}$ Tier-three plans are cash balance plans. ${ }^{40}$ A cash balance plan relies entirely on the dollar amount in the pension account, not on a formula. ${ }^{41}$ Under this model, the employer and employee make contributions to the retirement account, and the state adds a defined amount of interest credits. ${ }^{42}$ After retirement, KPERS annuitizes the employee's pension account and funds

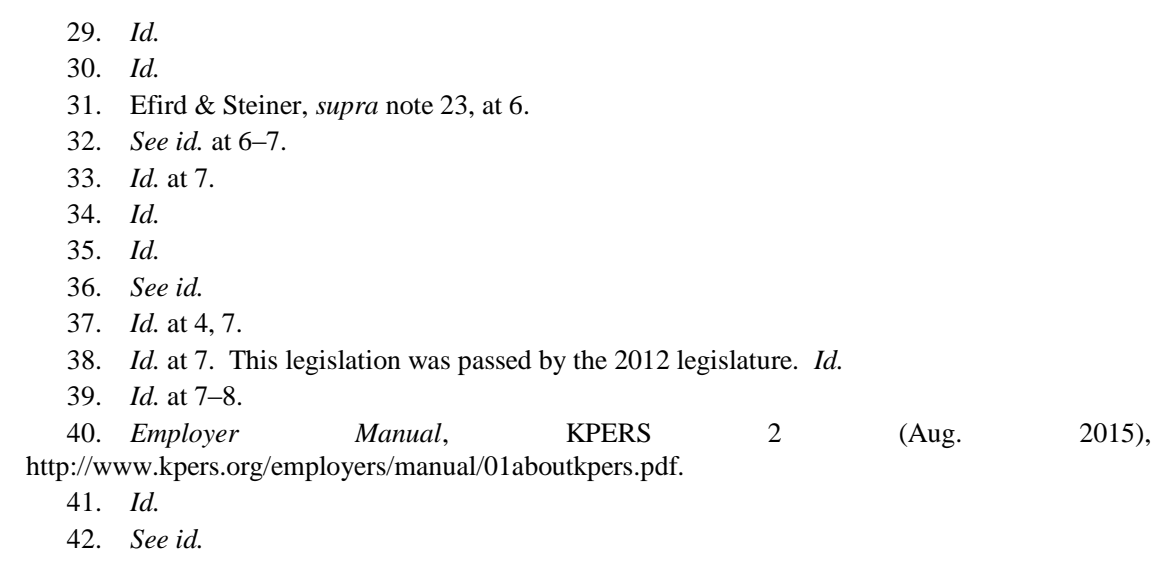


a lifetime of monthly payouts. ${ }^{43}$

The cash-balance plan reduces the potential for excessive liabilities by limiting employee benefits to the balance in their accounts, rather than guaranteeing monthly payments for life. ${ }^{44}$ It therefore provides the government with a more conservative alternative to the defined benefit plans of tier one and tier two. ${ }^{45}$ Although this adjustment decreases liabilities correlated with new members, it does little to resolve the liabilities flowing from tier-one and tier-two plans.

The defined benefit plans of tier one and tier two constitute the vast majority of the KPERS liability. ${ }^{46}$ Defined benefit plans guarantee particular benefits to members upon retirement. ${ }^{47}$ The benefits are calculated by utilizing a standard formula that factors in the employee's duration of employment and salary. ${ }^{48}$ For example, the KPERS benefit ratio was $1.75 \%$ of a member's final average salary. ${ }^{49}$ Imagine a retiring KPERS member with thirty years of state employment before January 2014 and a $\$ 50,000$ final average salary at the time of retirement. ${ }^{50}$ The member would be entitled to $1.75 \%$ of his or her average final salary for each of the thirty years of employment. ${ }^{51}$ In order to calculate the retirement benefit, the thirty years of employment is multiplied by the $1.75 \%$ retirement ratio, amounting to $52.5 \% .^{52}$ Consequently, $52.5 \%$ of the $\$ 50,000$ final average salary would constitute the retirement benefit. ${ }^{53}$ The hypothetical employee would retire with an annual monetary benefit of $\$ 26,250$. The retirement benefit would then be subject to statutory cost-of-living increases. ${ }^{54}$

\footnotetext{
43. Id.

44. See id.

45. FAQS About Cash Balance Pension Plans, U.S. DEP'T OF LABOR, http://www.dol.gov/ebsa/faqs/faq_consumer_cashbalanceplans.html (last visited Mar. 6, 2016).

46. See Conroy, supra note 3 , at 5 .

47. John L. Utz, Kansas Legislature's Legal Authority to Modify the Kansas Public Employees Retirement System (KPERS), KAN. POLICY InST. 1 (Sept. 2011),

http://www.kansaspolicy.org/researchcenters/budgetandspending/budgetandspendingstudies/d78173. aspx?type=view.

48. Id.

49. Id. at 2 (noting the statutory multiplier for participating service before 2014 was $1.75 \%$ ); see also BENEFITWISE NEWSLETTER, supra note 9, at 1-2 (noting the statutory multiplier for participating service January 2014 and after is $1.85 \%$ ).

50. See Utz, supra note 47 , at 2 .

51. See id.

52. See id.

53. See id.

54. Id. at 1 .
} 
The benefits accorded to KPERS members through defined benefit plans are at the core of the pension debt. ${ }^{55}$ Initially, the legislature appeared determined to reduce liabilities by simply stopping additional employees from joining failing pension plans. The creation of new tiers carrying less future liability was an attempt to simply cover previous obligations by lowering future obligations. By refraining from making meaningful modifications to current employee pension plans, the legislature cautiously refused to trigger the California Rule, which prohibits decreasing future benefits for current pension members unless the modification is also accompanied by new and offsetting advantages for the pension members. ${ }^{56}$

The strategy of restraining from meaningfully modifying pension plans proved to be the equivalent of disregarding a hole in a dam: the leak simply continues until the remaining water has drained. Similarly, the KPERS fund continues to shrink because of the inherent flaws contained in tier one and tier two plans.

Despite these problems, the Kansas legislature is growing increasingly aggressive with its remedies. In early 2015, the legislature approved $\$ 1$ billion worth of state-issued pension bonds. ${ }^{57}$ More importantly, it has also made several modifications to tier-one and tiertwo plans. ${ }^{58}$ The recent legislation pushes the limitations of the California Rule and begs the question: when do modifications to pension plans violate the rights of KPERS members?

\section{B. Kansas Pension Law}

Kansas judicial precedents concerning the legality of pension plan modifications is vague, likely caused by the lack of state regulation on the matter. The Kansas Constitution offers no guidance concerning state pension regulation, and Kansas statutory regulation is only applicable in limited circumstances.

Consequently, the Kansas Supreme Court created its precedent from

55. See Reed Holwegner, Q-1 Kansas Public Employees Retirement System Retirement Plans and History, KAN. Legislative ReSEARCH DeP'T 2-5, http://www.kslegresearch.org/KLRDweb/Publications/2015Briefs/2015/Q-1-

KansasPublicEmployeesRetirementSystemRetirementPlansandHistory.pdf (last visited Mar. 24, 2016).

56. See Singer v. City of Topeka, 607 P.2d 467, 475 (Kan. 1980) (quoting Allen v. City of Long Beach, 287 P.2d 765, 767 (Cal. 1955)).

57. See Carpenter, supra note 17.

58. BENEFITWISE NEWSLETTER, supra note 9, at 1-2. 
three key legal authorities. The first is Kansas statutory regulation, which prevents retroactive modifications to pension plans. ${ }^{59}$ The second is the Contract Clause of the United States Constitution, which the court employs to govern the contractual rights of employees to their pension benefits. ${ }^{60}$ Lastly, the Kansas Supreme Court adopted California judicial precedent for pension law, known as the California Rule. ${ }^{61}$ The California Rule is an interpretation of the Contract Clause, and it governs prospective modifications to pension plans. ${ }^{62}$

1. The Kansas Statutory Prohibition of Retroactive Modifications to State Pension Plans

Kansas statutory law protects employee pension plans from detrimental retroactive modifications. Retroactive modifications are modifications to pension benefits that have already accrued based on previously performed work. ${ }^{63}$ Section 74-4923(a) is the only Kansas statute restricting potential modifications to pension plans. ${ }^{64}$ It provides:

No alteration, amendment or repeal of this act shall affect the then existing rights of members and beneficiaries but shall be effective only as to rights which would otherwise accrue under this act as a result of services rendered by an employee after the alteration, amendment or repeal. This subsection shall not apply to any alteration or amendment of this act which provides greater benefits to members or beneficiaries, but any increase of benefits shall only be applicable to benefits payable on the first day of the month coinciding with or following the effective date of the alteration or amendment.

The statute prohibits the legislature from modifying existing rights in a manner that is detrimental to KPERS members. ${ }^{66}$ Existing rights are best explained as the rights already earned by the services of a member. ${ }^{67}$ In other words, the statute provides that the legislature cannot decrease benefits that were earned by an employee's past services. ${ }^{68}$

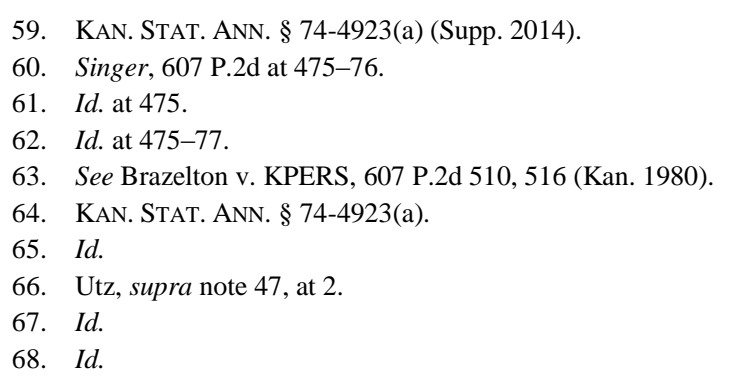


Brazelton v. KPERS provides an illustration of the Kansas Supreme Court's application of the statute. ${ }^{69}$ In Brazelton, members of the police and fire departments contributed a percentage of their compensation to a state pension plan. ${ }^{70}$ The legislature subsequently raised the required contribution rate by almost $5 \% .^{71}$ The amendment to the contribution rate applied retroactively, requiring the members to pay extra for time already worked. ${ }^{72}$ The court struck down the amendment as a violation of section 74-4923(a) and clarified that the retirement benefits of an employee cannot be retroactively changed "in a substantial manner by the unilateral action of the employer to the disadvantage or detriment" of the employee. ${ }^{73}$

The statute appears to substantially limit the legislature's ability to modify pension obligations. However, it is construed to only apply to retroactive modifications of existing rights. ${ }^{74}$ Not all modifications to current KPERS pension plans alter existing rights. Because existing rights do not include future benefits, an employee's future duration of employment does not constitute a period of time where an employee possesses the requisite existing rights. Although employees enter into pension agreements under the consideration of the initial terms of a pension plan, section 74-4923(a) does not prohibit unilateral modifications to the benefits an employee will receive for work to be performed after the modification. ${ }^{75}$

This conclusion is supported by Brazelton, where the court explained that if the amendment only modified current employee contributions for the future duration of employment, then such a modification may be acceptable under section 74-4923(a). ${ }^{76}$ Thus, the application of section 74-4923(a) is strictly limited to detrimental retroactive modifications. ${ }^{77}$ The legislature created no statute limiting its ability to make prospective modifications.

\footnotetext{
69. See Brazelton v. KPERS, 607 P.2d 510 (Kan. 1980).

70. Id. at 512 .

71. See id.

72. Id. at 516.

73. Id.

74. Id. at 514 .

75. See Kan. Stat. AnN. § 74-4923(a) (Supp. 2014).

76. Brazelton, 607 P.2d at 516 .

77. See id.
} 
2. The Contract Clause and the California Rule: Prospective Modifications to Pension Plans

Although section 74-4923(a) only prohibits retroactive modifications to state pension plans, the Kansas Supreme Court has also created a judicial precedent restricting prospective modifications. The Kansas Supreme Court has determined that statutorily defined pension benefits create enforceable contracts between the state and the members of the pension plan. ${ }^{78}$ Therefore, the court has determined the Contract Clause of the United States Constitution governs the legality of prospective modifications. $^{79}$

The Contract Clause stipulates that "No State shall ... pass any ... Law impairing the Obligation of Contracts." ${ }^{\text {"I }}$ In 1980 - when the Kansas Supreme Court first determined that the Contract Clause applies to state pensions - states varied widely on interpreting the Contract Clause's effect on state pension rights. ${ }^{81}$ Typically, courts have held that the test for determining whether a state law violates the Contract Clause is whether the law (1) operates in substantial impairment of a contract, (2) serves a legitimate state or public purpose, and (3) adjusts the rights and responsibilities of the parties based upon reasonable conditions and is of a character appropriate to the public purpose for the law. ${ }^{82}$

In Singer v. City of Topeka - the landmark case for Kansas pension law - the Kansas Supreme Court considered several methods of applying the Contract Clause in a manner applicable to state pension plans. ${ }^{83}$ Most importantly, the court analyzed when prospective modifications should qualify as an impairment to the contract. ${ }^{84}$ For example, the Supreme Court of Arizona determined that any modification to a pension agreement without the consent of the employee constitutes an impairment to the contract and is therefore unlawful. ${ }^{85}$ Other states allowed their legislatures to unilaterally implement prospective

\footnotetext{
78. Galindo v. City of Coffeyville, 885 P.2d 1246, 1254 (Kan. 1994).

79. Singer v. City of Topeka, 607 P.2d 467, 475 (Kan. 1980).

80. U.S. CONST., art. I, § 10, cl. 1.

81. Singer, 607 P.2d at 473 .

82. See, e.g., Denning v. KPERS, 180 P.3d 564, 569 (Kan. 2008); Bd. of Educ. of Unified Sch. Dist. No. 443 v. Kan. State Bd. of Educ., 966 P.2d 68, 77 (Kan. 1998); Zimmerman v. Bd. of Cty. Comm'rs, 218 P.3d 400, 425 (Kan. 2009).

83. Singer, 607 P. $2 \mathrm{~d}$ at $473-75$.

84. See id. at 475-77.

85. See Yeazell v. Copins, 402 P.2d 541, 545-47 (Ariz. 1965); see also Singer, 607 P.2d at $474-75$.
} 
modifications to pension benefits because they refused to recognize contractual pension rights for current employees. ${ }^{86}$ California held that a state may only make a prospective modification to a contract if it is a "reasonable modification." 87 In an effort to create a flexible rule, Kansas adopted the California Rule in its entirety. ${ }^{88}$

By adopting the "reasonable modification" terminology from the California Supreme Court, the Kansas Supreme Court added a fourth step to determining whether a prospective modification violates the Contract Clause. The fourth step can be broken into two parts to determine whether pension modifications are reasonable. ${ }^{89}$ First, the modification must bear a material relation to the pension fund's successful operation. ${ }^{90}$ Second, any "changes in a pension plan which result in disadvantage to employees should be accompanied by comparable new advantages." 91

The first part of the California Rule mandates that the modification positively correlate with the success of the pension. ${ }^{92}$ The Kansas Supreme Court refrained from articulating clear guidelines to determine when a modification positively correlates to a pension fund's success. ${ }^{93}$ Rather, Kansas courts determine the issue on a case-by-case basis and analyze whether the pension modifications align with the goals of the Kansas pension system, such as protecting the financial integrity of the system or "other compelling reason[s]." 94

The second part of the rule - the balancing test-is the characteristic that differentiates the California Rule from the vast majority of other states. $^{95}$ It mandates any disadvantage resulting from a modification must be accompanied by a comparable new advantage. ${ }^{96}$ In comparing

\footnotetext{
86. See Singer, 607 P.2d at 473-74.

87. Id. at 475-76; see also Allen v. City of Long Beach, 287 P.2d 765, 767 (Cal. 1955).

88. Singer, 607 P.2d at 475-76; Allen, 287 P.2d at 767.

89. Singer, 607 P.2d at 475 .

90. Id.

91. Id. (quoting Allen, 287 P.2d at 767).

92. See id. 475-76; Allen, 287 P.2d at 767.

93. Singer, 607 P.2d at $475-76$.

94. Lea E. Selleck, Post-Retirement Employment Restrictions on Public Employees in Kansas, 5 KAN. J.L. \& PUB. POL'Y 199, 206 (1996) (quoting Brazelton v. KPERS, 607 P.2d 510, 517 (Kan. 1980)).

95. See Amy B. Monahan, Statutes as Contracts? The "California Rule" and Its Impact on Public Pension Reform, 97 IowA L. Rev. 1029, 1032-33, 36 (2012) ("While the courts permit reasonable modifications of the contract prior to retirement, they do not allow any disadvantageous modifications unless the modifications are offset by comparable new advantages.").

96. Singer, 607 P.2d at 475 ; Allen, 287 P.2d at 767.
} 
the potential advantages with disadvantages, the court does not consider the effect on individual employees, but rather, it considers the effects of the modification on the employees as a group or groups. ${ }^{97}$ The rule has no other provisions the court must consider. By adopting the rule, the court avoided overly descriptive guidelines, and in doing so, gave itself great discretion to resolve fact-specific circumstances. ${ }^{98}$

As a result, the California Rule affords extensive protection to state and municipal employees' prospective pension benefits. California courts have consistently enforced the balancing test to disallow changes in pension plans reducing monetary benefits without also adding a comparable benefit or simultaneously reducing employee contribution rates. ${ }^{99}$ Likewise, Kansas courts do not allow the legislature to increase employee contribution rates without a comparable increase in benefits or similar advantage. ${ }^{100}$

\section{ANALYSIS}

This section will begin by addressing vested contractual rights under current Kansas precedent, providing clarification for when KPERS members possess plausible claims arising from prospective pension modifications. Second, this section will demonstrate that the Kansas Supreme Court had reasonable and worthy policy purposes for adopting the California Rule, and therefore, the initial policy purposes provide an appropriate measuring stick to analyze the rule's effectiveness. Third, this section will illustrate that the California Rule has not only failed to fulfill its original policy purposes, but it also operates in a manner that directly conflicts with them. Lastly, this section will clarify how the United States Supreme Court's analysis of the Contract Clause in $M \& G$ Polymers USA, LLC v. Tackett ${ }^{101}$ explicitly rejects the legal analysis relied on by the California Rule's interpretation of the Contract Clause. Ultimately, this Comment will advocate for the Kansas Supreme Court to abandon the California Rule.

\footnotetext{
97. Singer, 607 P.2d at 475.

98. Selleck, supra note 94 , at 207

99. Volokh, supra note 14, at 6-9.

100. Selleck, supra note 94, at 207.

101. M\&G Polymers USA, LLC v. Tackett, 135 S. Ct. 926 (2015).
} 


\section{A. KPERS Members' Rights to Their Pensions and the Distinction Between Vested and Non-Vested Rights}

Kansas courts have created a grey area of precedent governing the most fundamental element of Kansas pension law: vested contractual rights. Because prospective modifications to pension plans must impair a KPERS member's contractual rights to be considered a violation of the Contract Clause, a KPERS member must first obtain the contractual rights to be protected. ${ }^{102}$ An employee possesses absolute contractual rights once they are deemed a vested member of the retirement plan. ${ }^{103}$ Once obtained, vested rights are substantial and are afforded the protection of the United States Contract Clause and the California Rule's additional interpretation of it. ${ }^{104}$ Therefore, the difference between vested KPERS members and non-vested KPERS members is essential for determining a member's prospective pension rights and the Kansas legislature's ability to prospectively modify pensions. However, it can be difficult to ascertain when KPERS members specifically obtain vested rights to the entirety of their pension benefits. ${ }^{105}$

The Kansas Public Employees Retirement Act of 2009 sets the upper boundary for when a KPERS member must obtain vested rights. ${ }^{106}$ Section 74-49,208 clarifies that KPERS members obtain "a vested retirement benefit in the system" after five years of credited employment. ${ }^{107}$ Although effective since 2009, Kansas courts have not utilized section 74-49,208 in a judicial opinion, rendering the statute open to interpretation. The statute's vesting period does not conflict with federal law limitations, and there is no reason to believe Kansas courts would find otherwise. ${ }^{108}$ Consequently, it is reasonable to assume KPERS members must obtain vested rights after five years of employment.

However, KPERS members may obtain vested rights sooner than statutory law requires. ${ }^{109}$ The Kansas Supreme Court's previous analysis

\footnotetext{
102. Galindo v. City of Coffeyville, 885 P.2d 1246, 1253 (Kan. 1994).

103. See Singer v. City of Topeka, 607 P.2d 467, 473 (Kan. 1980).

104. Id. at 475 .

105. See id. at 474-75.

106. KAN. STAT. ANN. $\S \$ 74-49,201,74-49,208$ (2008).

107. Id. § 74-49,208.

108. See Volokh, supra note 14, at 10 (allowing states to determine there is no contractual right to pension benefits indicates the Supreme Court would not find a lack of protection for a state recognizing vested contractual rights).

109. See Selleck, supra note 94, at 206.
} 
concerning vested rights provides insight into when the court is likely to grant vested rights to KPERS members. When the Kansas Supreme Court adopted the California Rule in 1980, it had the opportunity create a rigid and clear rule for determining when employees obtain vested rights in their pensions. ${ }^{110}$ There were a variety of persuasive cases on the matter, ranging greatly in their outcomes. ${ }^{111}$ The Supreme Court of Arizona provided a clear and strict rule that designated all contracts vested upon employment. ${ }^{112}$ Other states held that contracts did not vest until the employee's retirement. ${ }^{113}$ The Kansas Supreme Court held that vested rights are earned after a "reasonable period of time."114 Consequently, Kansas judicial precedent fails to determine when employees specifically obtain vested rights in their KPERS pension plans.

However, the court did establish guidelines for determining what constitutes a "reasonable period of time." 115 The outside parameters are gauged by time considerations. A reasonable period of time must occur between an employee's first day of employment and retirement. ${ }^{116}$ In Brazelton v. KPERS, the Kansas Supreme Court clarified, "when a person accepts employment with a governmental entity and becomes a participating member of the retirement system, he or she gains certain rights." 117 Therefore, although a new employee may not possess vested rights for every aspect of KPERS benefits, he or she may gradually accrue certain rights over the course of employment. ${ }^{118}$ Moreover, certain rights begin immediately after accepting employment with the state or municipality. ${ }^{119}$

The employees' actions are also utilized to determine when employees specifically obtain vested rights in the entire pension plan. ${ }^{120}$ The Kansas Supreme Court provides "[c]ontinued employment over a reasonable period of time during which substantial services are furnished

\footnotetext{
110. See Singer, 607 P.2d at 474-75.

111. See id.; Yeazell v. Copins, 402 P.2d 541, 545 (Ariz. 1965); Tait v. Freeman, 57 N.W.2d 520, 522 (S.D. 1953); Hickey v. Pension Bd. of Pittsburgh, 106 A.2d 233, 238 (Pa. 1954).

112. Yeazell, 402 P.2d at 545 .

113. Singer, 607 P.2d at 474; see also Tait, 57 N.W.2d at 522.

114. Singer, 607 P.2d at 474 .

115. Id.

116. See id.

117. Brazelton v. KPERS, 607 P.2d 510, 514 (Kan. 1980).

118. See Selleck, supra note 94, at 206.

119. Brazelton, 607 P.2d at 514.

120. See Singer, 607 P.2d at 474.
} 
to the employer, plan membership is maintained, and regular contributions into the fund are made ... cause the employee to acquire a contract right in the pension plan." ${ }^{121}$ The court merely describes actions that are typically associated with those of a contributing pension member and also mandates the employee provide "substantial services" to the employer. The Kansas Supreme Court and the California Rule provide little guidance on establishing when an employee provides the requisite amount of "substantial services." Rather, Kansas courts determine when rights vest on a case-by-case basis. ${ }^{122}$

In Singer, the court granted vested contractual rights to a firefighter after eleven years of credited service. ${ }^{123}$ At the time, the state firefighter pension plan designated vested rights as accruing after fifteen or twenty years of credited service, depending on which pension plan members opted to join. ${ }^{124}$ Thus, the Kansas Supreme Court illustrated it is willing to grant vested rights to KPERS members before it is statutorily obligated. Although it remains unclear whether the court is willing to grant fully vested contractual rights before the statutorily mandated five years, KPERS members lacking five years of service still possess a plausible claim for vested contractual rights to future pension benefits.

The determination of when vested rights occur is vital. Vested rights not only inform employees when they have obtained contractual rights to the benefits they will rely upon in retirement, but they are also the line that the Kansas legislature must consider when contemplating the legality of prospective modifications to pension plans. By refusing to firmly distinguish between two categories that have vastly different ramifications, Kansas courts have created a grey area of precedent governing the most basic element of pension law.

\section{B. The Purposes and Policy Considerations Underlying the Implementation of the California Rule}

The Kansas Supreme Court's original policy purposes for adopting the California Rule provide an appropriate measuring stick for determining the rule's success. The court adopted the California Rule with two significant and interrelated goals in mind. ${ }^{125}$ First, the court

\footnotetext{
121. Id.

122. Brazelton, 607 P.2d at 514 .

123. Singer, 607 P.2d at 474 .

124. Selleck, supra note 94, at 206.

125. See Singer, 607 P.2d at 475.
} 
adopted the rule to be flexible and capable of adapting to the changing needs of the state system. ${ }^{126}$ Second, the rule was meant to provide broad protection for state and municipal employees. ${ }^{127}$ The Kansas Supreme Court articulated noteworthy policy purposes underlying the adoption of the California Rule, and thus, the purposes are important considerations for judging the rule's success and understanding why Kansas courts continue to employ it.

The California Rule allows reasonable prospective modificationsassuming the modifications contain benefits to counterbalance any detrimental aspects - to pension plans for a variety of public policy purposes. ${ }^{128}$ Similarly, the Kansas Supreme Court has explicitly recognized that when changes are necessary for the greater good of the state, modifications may be made to state pension plans. ${ }^{129}$ In Brazelton, the court clarified that it may be necessary to modify pension plans "to preserve or protect the pension system; to maintain flexibility; to permit necessary adjustments due to changing conditions to protect the beneficial purpose of the system; to maintain the system on a sound actuarial basis or by reason of administrative necessity."130 The court also stated that unilateral changes may be made when they are required or justified by a compelling reason, such as the protection of the pension system's financial integrity. ${ }^{131}$

The Kansas Supreme Court explicitly clarified that a primary concern for Kansas pension law is to protect the pension system and ensure its adequate funding. ${ }^{132}$ The court's reasoning was sensible and clear, even identifying one of the contributing causes of the current Kansas pension deficit - changing conditions - that led to the economic recession that drastically increased Kansas pension liabilities. ${ }^{133}$ Not only did the court recognize the importance of remaining flexible to respond to changing conditions, but it also recognized that the financial integrity of the system is a valid reason to allow modifications to pension plans. ${ }^{134}$ The purpose of permitting such modification is "to protect the

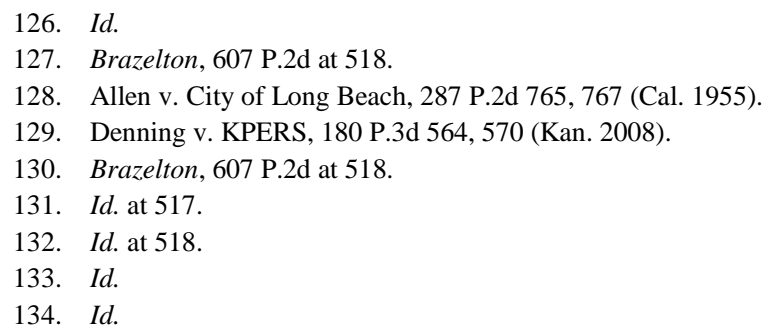


beneficial purpose of the system." ${ }^{35}$ The court's position could not be more clear-by implementing pension law with the ability to protect the successful operation of the pension system, the court sought to create a rule capable of maintaining a pension system able to provide for state employees and retirees.

In addition, the Kansas Supreme Court has also repeatedly, and unambiguously, identified the protection of state employees as a primary concern of Kansas pension law. ${ }^{136}$ The court cited the importance of pensions for inducing quality employees into initially accepting a governmental position, specifically stating that "[p]ublic employment seldom pays as much as a comparable job in the private sector. A pension to be received upon retirement is a prime inducement in securing qualified workers and avoiding the expense of a high turnover rate."137 The court further clarified its protection of state employee pensions with a powerful explanation on the matter:

It would take a compelling reason indeed, for this Court to hold that the [state or city] may, with the stroke of the pen, whether encouraged by the State Legislature or not, renege on its contractual commitments to these men and women who have not reneged on their commitments to our citizens. 138

The court correctly recognized that the very reason Kansas pension plans exist is to provide for the men and women serving the state. Consequently, the Kansas Supreme Court showed two essential purposes behind Kansas pension law: the importance of protecting the system and the importance of honoring the state's commitment to employee pensions.

The Kansas Supreme Court provides sound reasoning for the policy purposes underlying Kansas pension law. Although allowing the possibility of pension modifications while simultaneously refusing to allow the state to renege on its commitment to employees seems contradictory, the court recognized that the relationship between pension funding and employee pension rights is not adversarial. Rather, the health of the pension system is necessary to ensure employee pension rights remain unharmed. Without the means to provide benefits to employees beyond retirement, Kansas would be forced to renege on its

135. Id

136. See id. at 514; Singer, 607 P.2d at 471.

137. Brazelton, 607 P.2d at 515.

138. Singer, 607 P.2d at 472 . 
commitment to provide retirement benefits and would consequently fail to achieve the law's purpose of protecting state pension members.

Although the Kansas Supreme Court provided sound rationale for achieving worthy motives, it made a critical error in declining to create its own pension law. Rather, it adopted the California Rule to achieve Kansas's policy purposes.

\section{The California Rule Conflicts with its Original Policy Purposes}

The California Rule fails to protect the Kansas pension system and, as a consequence, harms the state employees the rule seeks to protect. Examination of the California Rule's key feature-preventing detrimental modifications to prospective pension plans without additional and comparable benefits-illustrates a domino effect of problems stemming from the rule.

The California Rule confines the Kansas legislature's ability to make any meaningful prospective modifications to state pension plans. ${ }^{139}$ The inability to decrease future employee benefits or contribution rates without equivalent advantages locks Kansas and its public employees into pension plans designed to yield efficient results in an economic market existing years, even decades, previously. ${ }^{140}$ It produces rigid pension plans that are incapable of adapting to an unpredictable free market or utilizing negotiations to appropriately reform the pension system. $^{141}$

Without the ability to sufficiently reduce pension liabilities, the Kansas legislature has been forced to take increasingly desperate measures in an attempt to remedy the pension deficit. When the legislature opted to create new tiers of KPERS for incoming employees, the new plans carried increased contribution rates and essentially passed previous liabilities onto new members uncorrelated with the previous pension problems. Such a result is commonplace among states that protect prospective benefits because the inability to correctly allocate liabilities naturally leads to new employees bearing much of the financial burden while receiving disproportionately less benefits. ${ }^{142}$ Not only is

\footnotetext{
139. Utz, supra note 47 , at $1-3$.

140. See Volokh, supra note 14, at 2 ("[T]he California rule, by freezing public-employee pension benefits in place, deprives governments of the flexibility to alter some of the future conditions of public employment.").

141. Id.

142. Liz Farmer, How are Pensions Protected State-by-State?, GovernING (Jan. 28, 2014),
} 
the result inequitable, but it also directly contradicts the Kansas Supreme Court's reasoning for adopting the California Rule. The Kansas Supreme Court cited the importance of protecting pension rights for enticing quality workers from the private sector, ${ }^{143}$ but by disproportionately placing additional obligations on the newest public employees, the rule hardly induces new hires.

Moreover, closing pension plans does not eliminate a pension's funding gap. ${ }^{144}$ Although the plan may be closed to new members, the state's obligation to pay for the plan's benefits still remains. ${ }^{145}$ The Kansas legislature's closure of the tier one and tier two plans proved to be the equivalent of slapping a Band-Aid on a gunshot wound. The legislature may have slowed the hemorrhaging of KPERS liabilities, but it did not resolve the ultimate problem. Kansas's \$9 billion pension shortfall illustrates the inadequacy of simply closing failing pension plans.

As a result, the Kansas legislature turned to a more drastic measure-passing a resolution to issue $\$ 1$ billion worth of pension bonds. Although the issuance of $\$ 500$ million worth of bonds in the past provided a temporary solution for Kansas, it is exceptionally risky. ${ }^{146} \mathrm{~A}$ few previous pension bond deals exemplify the dangers of Kansas's situation. Similarly suffering from the California Rule's ramifications, Stockton, California issued pension obligation bonds to resolve its pension deficit. ${ }^{147}$ The plan resulted in bankruptcy. ${ }^{148}$ Suffering from the California Rule's ramifications, San Bernardino, California issued pension obligation bonds to resolve its pension deficit. ${ }^{149}$ The plan resulted in bankruptcy. ${ }^{150}$ Detroit, Michigan issued pension obligation

\footnotetext{
http://www.governing.com/finance101/gov-pension-protections-state-by-state.html.

143. See Brazelton, 607 P.2d at 515.

144. Pension Funding Gaps, AARP 3, http://assets.aarp.org/www.aarp.org_/articles/work/pension-funding-gap.pdf (last visited Mar. 7, 2016).

145. Id.

146. See Rob Garver, Kansas Weighs Risky Bet to Cover Its Pension Needs, THE Fiscal Times (Feb. 10, 2015), http://www.thefiscaltimes.com/2015/02/10/Kansas-Weighs-Risky-Bet-Cover-ItsPension-Needs.

147. Id.

148. Id.

149. Karol K. Denniston, San Bernardino's Financial Gordian Knot re: Chapter 9 Bankruptcy, NAT'L L. REV. (May 27, 2015), http://www.natlawreview.com/article/san-bernardino-s-financialgordian-knot-re-chapter-9-bankruptcy.
}

150. Id. 
bonds to resolve its pension deficit. ${ }^{151}$ The plan resulted in bankruptcy. ${ }^{152}$

The hazards associated with pension obligation bonds are not difficult to understand, but rather, they arise from the most basic elements of the pension bond strategy. A pension bond plan revolves around three fundamental steps. First, the government borrows money. ${ }^{153}$ Second, the government reinvests it. ${ }^{154}$ Third, the government hopes the investment receives a higher return than originally borrowed. ${ }^{155}$ Experts view the concept as speculative gambling, similar to the endeavors of an investor at Goldman Sachs, ${ }^{156}$ except that in Kansas's scenario, the stakes are much higher. An unfortunate investment could potentially result in the squandering of hard earned retirement benefits of 289,000 Kansas employees, or at the very least, a crippling burden placed upon Kansas taxpayers. ${ }^{157}$ Steve Anderson, the former Kansas budget director and current fiscal policy fellow at the Kansas Policy Institute, openly rejects the idea of pension bonds as a solution, citing that it avoids the true problem and shifts the debt to the taxpayers. ${ }^{158}$

The Kansas infrastructure is also vulnerable because of the pension crisis. School employees constitute $55 \%$ of state pension members. ${ }^{159}$ Kansas lawmakers want the court to strongly consider deeming pension funding a portion of school aid. ${ }^{160}$ Kansas is required to spend $\$ 3,838$ per student on an annual basis for the public school system. ${ }^{161}$ Currently, any money devoted to pension funding does not qualify as a portion of the required amount for school aid. ${ }^{162}$ By labeling teachers' pension funding a part of school funding, Kansas can effectively double-count a

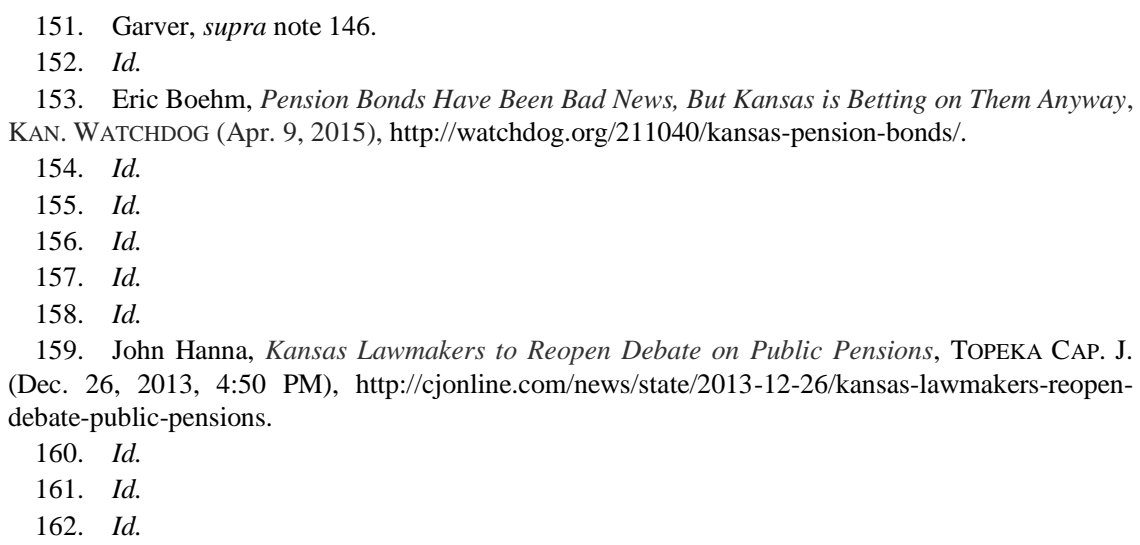


single payment and reduce the state's liabilities. ${ }^{163}$ Although this may be an efficient accounting standard, it carries alarming real-world repercussions. The Kansas Association of School Boards believes that virtually all money available for school districts will be redirected to pension funds. ${ }^{164}$ In essence, the strategy diverts vital resources from Kansas classrooms to KPERS pension plans.

When considering the totality of the California Rule's results, it becomes evident the rule fails to uphold the Kansas Supreme Court's initial policy considerations for implementing it. The rule effectively prohibits the Kansas legislature from making meaningful modifications to a flawed pension system and leaves KPERS members in a state of uncertainty; and consequently, it endangers the KPERS system and the members it is meant to protect.

\section{The California Rule Conflicts with the United States Supreme Court's Application of the Contract Clause}

The Kansas Supreme Court possesses the authority to reform Kansas pension law without conflicting with federal law. Although the California Rule is an interpretation of the United States Contract Clause, the Kansas Supreme Court is not required to follow the California Rule. ${ }^{165}$ In actuality, the California Rule affords much greater protection to pension plans than the United States Supreme Court has indicated is necessary.

The California Rule produces two basic contractual results, both of which inherently contradict fundamental contract principles. First, the California Rule leads to the interpretation of statutes as contracts with very little concern as to whether the legislature actually intended to enter into a contractual agreement. ${ }^{166}$ Second, the California Rule then interprets the United States Contract Clause to provide vested contractual rights for life. ${ }^{167}$ The United States Supreme Court has long disagreed with the California Rule's first result, explicitly warning against the supposition that the legislature may enter into statutorily defined contracts without the legislature's explicit consent. ${ }^{168}$ Although the

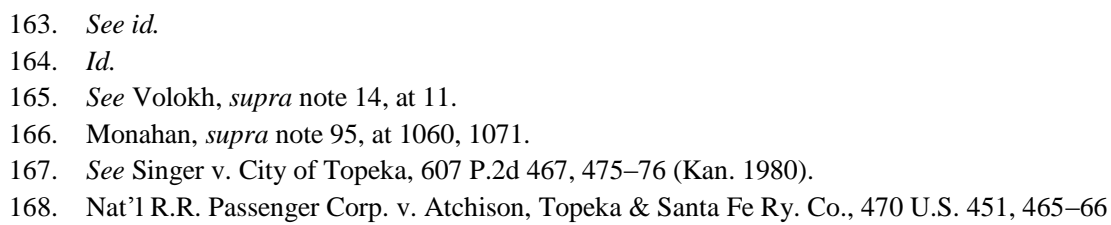


Court has maintained this legal principle for decades, the California Rule has endured.

As for the California Rule's second effect, a majority of states refuse to afford protection to prospective modifications that are as extensive as the California Rule provides, offering an indication that the California Rule delivers more protection than the Contract Clause requires. However, the California Rule not only provides more protection than the Contract Clause requires, it also provides more protection than the Contract Clause is intended to provide.

The 2015 United States Supreme Court decision $M \& G$ Polymers USA, LLC v. Tackett ${ }^{169}$ unambiguously clarifies that the California Rule is defective pension law. ${ }^{170}$ In $M \& G$ Polymers, the Court overturned International Union, United Automobile, AeroSpace, \& Agricultural Implement Workers of America v. Yard-Man, Inc., ${ }^{171}$ a longstanding and controversial Sixth Circuit Court of Appeals decision, which held that ambiguous provisions governing collective bargaining retirement benefits should be construed to vest for life. ${ }^{172}$ In Yard-Man, the Sixth Circuit determined that although the collective bargaining agreement contained a specified duration, the provision identifying the retirement benefits lacked such a duration, and therefore, constituted vested benefits for the remainder of the employees' lives. ${ }^{173}$ The court purportedly used the basic principles of contract interpretation to reach its conclusion, and it justified its decision by explaining that retirement benefits are "typically understood as a form of delayed compensation." "174 Consequently, the court determined the parties possessed an implicit intent for the retirement benefits to vest for life. ${ }^{175}$

In $M \& G$ Polymers, the United States Supreme Court rejected virtually every aspect of the Sixth Circuit's analysis in Yard-Man. ${ }^{176}$ The Supreme Court found that Yard-Man disregards the importance of determining the intention of the parties and "violates ordinary contract principles by placing a thumb on the scale in favor of vested retiree

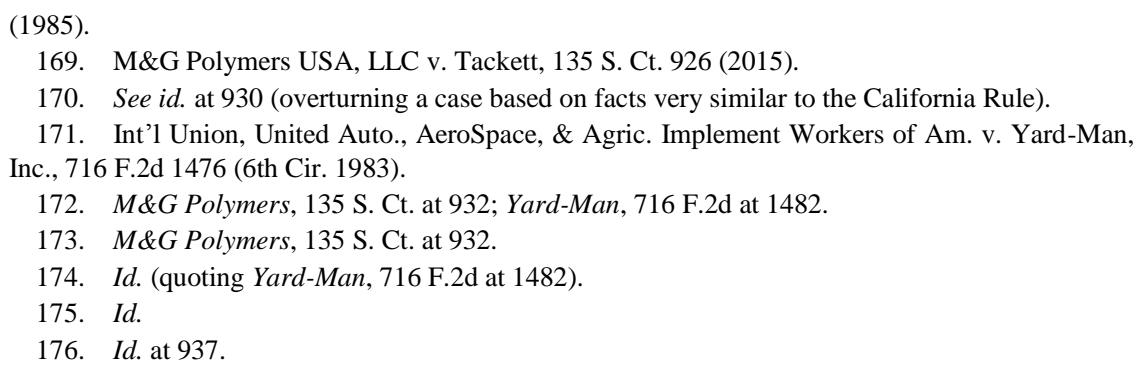


benefits in all collective-bargaining agreements."177 Yard-Man not only misapplied the contractual principles it utilized, but it also completely disregarded other fundamental contractual principles. ${ }^{178}$ In the words of the Supreme Court, "the Court of Appeals failed to consider the traditional principle that 'contractual obligations will cease, in the ordinary course, upon termination of the bargaining agreement.",179

The Supreme Court's explicit rejection of Yard-Man is significant for Kansas pension law because of the astounding similarities shared by the Yard-Man rule and the California Rule. Although Yard-Man addressed a private sector issue detached from the Contract Clause, the ultimate analysis for determining the intention of employers to create vested pension benefits relies upon the same contractual principles in both public and private sectors. ${ }^{180}$ Similar to the California Rule, the court in Yard-Man employed contract principles to interpret retirement benefits vest for life, drastically limiting any ability to legally alter the prospective aspects of pension plans. ${ }^{181}$ Also similar to the California Rule, the Yard-Man interpretation was in the minority; no other circuit court agreed with the Sixth Circuit that pensions create irrevocable lifetime promises. ${ }^{182}$ The ramifications of the rules are also alike. Employers located within the Sixth Circuit found themselves trapped in strict, non-negotiable agreements that vastly increased liabilities. ${ }^{183}$ Unfortunately, before the Supreme Court rejected its flawed analysis, the Yard-Man rule led to numerous bankruptcies. ${ }^{184}$

However, KPERS is not necessarily predestined to a similar fate. As the United States Supreme Court illustrated in $M \& G$ Polymers, Kansas is not only legally able to abandon the California Rule, but its abandonment

\footnotetext{
177. Id. at 935 .

178. Id

179. Id. at 937 (quoting Litton Fin. Printing Div. v. NLRB, 501 U.S. 190, 207 (1991)).

180. Frances Rogers, U.S. Supreme Court Holds: There Is No Presumption That Retiree Medical Benefits Are Vested, CAL. PuB. AgEnCy LABOR \& EMP'T Blog (Jan. 27, 2015), http://www.calpublicagencylaboremploymentblog.com/retirement/u-s-supreme-court-holds-there-isno-presumption-that-retiree-medical-benefits-are-vested/.

181. Id.

182. See Teague Paterson, Yard-Man Is Dead, Long Live Yard-Man!, BEESON TAYER \& Bodine (Jan. 28, 2015), http://www.beesontayer.com/2015/01/yard-man-is-dead-long-live-yard-man/.

183. Gilbert P. Brosky, United States: Ding-Dong, Yard-Man Is Dead! Supreme Court Decision in Tackett a Huge Win For Employers in The Retiree Healthcare Arena, MONDAQ (posted Jan. 28, 2015, updated Feb. 5, 2015), http://www.mondaq.com/unitedstates/x/371996/Employee+Benefits+Compensation/DingDong+Yar $\mathrm{dMan}+\mathrm{Is}+$ Dead+Supreme+Court+Decision+in+Tackett+a+Huge+Win+for+Employers+in+the+Reti ree+Healthcare+Arena.

184. Id.
} 
would also align the state with fundamental legal principles. Considering the Kansas Supreme Court applies the California Rule as an attempt to construe the federal Contract Clause, it would be irrational to continue its application after the United States Supreme Court has explicitly rejected such an interpretation.

\section{RECOMMENDATION}

The Kansas Supreme Court should abandon the California Rule. The United States Supreme Court's decision in $M \& G$ Polymers USA, LLC v. Tackett openly displayed the fundamental flaws underlying the California Rule's reasoning. ${ }^{185}$ Interpreting a non-durational statute or contract provision to produce nearly irreversible lifetime benefits conflicts with basic contractual principals. ${ }^{186}$ Thus, the Kansas Supreme Court should refuse to interpret statutorily defined pension benefits as unalterable contractual agreements.

Pension laws vary drastically by state, providing the Kansas Supreme Court with several viable alternatives to the California Rule. Certain states brand pension benefits as mere gratuities, free to be unilaterally altered in a retroactive or prospective manner. ${ }^{187}$ Other states classify pension benefits as property rights, triggering due process concerns. ${ }^{188}$ On the most restrictive end of the spectrum, certain states are compelled by their state constitutions to grant employees contractual rights to retroactive and prospective pension benefits. ${ }^{189}$ The Kansas Constitution contains no such restriction, which provides the Kansas Supreme Court with a second chance to select the legal theory properly suited to address the needs of the pension system.

Moreover, a diversion from the California Rule would not be uncharted territory. ${ }^{190}$ Of the twelve states that originally adopted the California Rule, three states have diverged from its standard in meaningful ways. ${ }^{191}$ In certain circumstances, Massachusetts has deviated from the balancing test contained in the California Rule, allowing detrimental alterations to pension benefits without comparable

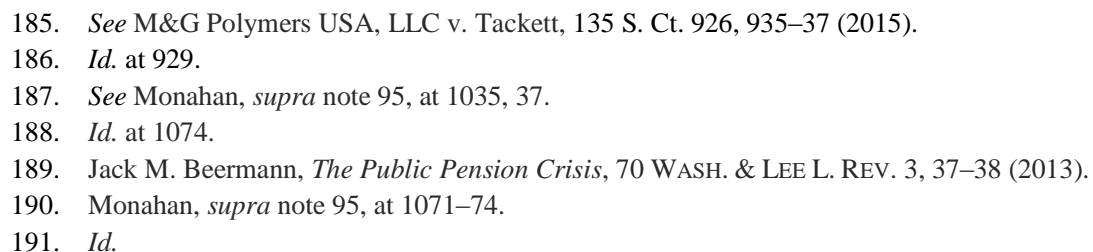


new advantages. ${ }^{192}$ The Oregon Supreme Court upheld a statutory amendment that prospectively removed a tax exemption on public employee pension benefits. ${ }^{193}$ Most significantly, the Colorado Supreme Court appeared to completely diverge from the California Rule by refusing to recognize a statutorily defined cost of living adjustment as a contract. ${ }^{194}$

The Kansas Supreme Court should follow the lead of its neighboring state and end the flawed recognition of statutorily defined pension benefits as contracts. In 2014, the Colorado Supreme Court addressed pension modifications in Justus v. State ${ }^{195}$ Similar to Kansas, Colorado faced a crippling pension deficit. ${ }^{196}$ As a result, the Colorado legislature capped cost of living adjustments. ${ }^{197}$ The Colorado Supreme Court determined that the relevant statute did not form a contract, and therefore, employees possessed no contractual rights to the prospective cost of living adjustments. ${ }^{198}$ The court recognized the longstanding rule that statutory enactments do not create contracts unless there is a clear indication of the legislature's intent to be bound. ${ }^{199}$ Although the concurring opinion encouraged the majority to officially end its precedent that labels Colorado's statutorily defined pension plans as contracts, the majority opinion in Justus stopped short of explicitly rejecting its precedent. ${ }^{200}$

The Kansas Supreme Court should advance the rationale utilized in Justus and explicitly reject the Kansas precedent labeling statutorily defined pension benefits as contracts. As the United States Supreme Court has stated, "the principal function of a legislature is not to make contracts, but to make laws that establish the policy of the state. Policies, unlike contracts, are inherently subject to revision and repeal." ${ }^{201}$ The Court has been clear on this matter, explicitly warning against interpreting a statute as a contract without the legislature's consent because it "limit[s] drastically the essential powers of a legislative

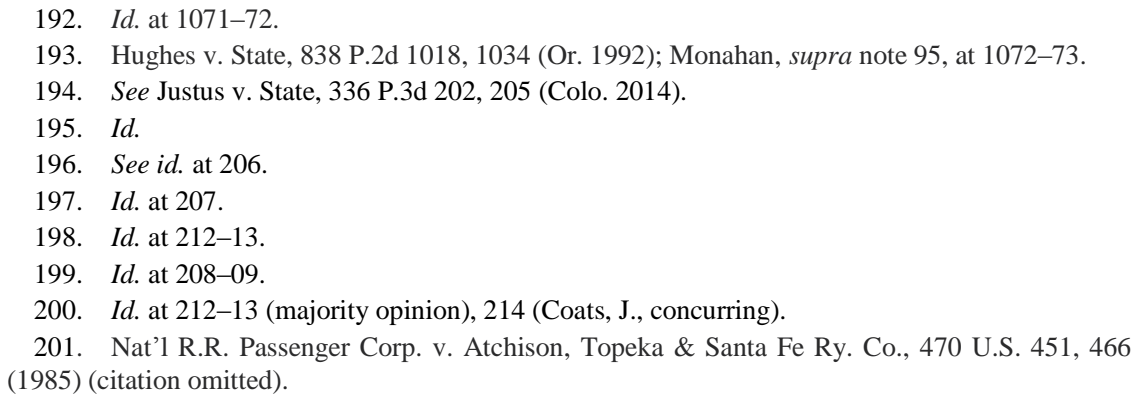


body."202 The Kansas Supreme Court should recognize the United States Supreme Court's reasoning and free Kansas from the shackles of the California Rule.

Although abandoning a rule providing extensive protection for pension members may appear to be a worrisome proposition-perhaps why the California Rule has endured for so long-this hesitancy is predicated on a false sense of protection for pension members. The American dream revolves around opportunity and finding a better life. Underlying the American dream is the prospect of an enjoyable retirement. It is a natural inclination to protect the benefits that enable a storybook ending to the American dream. This inclination is illustrated by the Kansas Supreme Court's analysis in Singer v. City of Topeka, where it adopted the California Rule based almost entirely on policy considerations. $^{203}$ However, neither legal principles nor policy considerations support the grant of unalterable lifetime pension benefits.

In truth, abandoning the California Rule would not only remove a precedent borne through faulty contractual reasoning, but it would also relieve Kansas of the restrictions that contributed to the current pension deficit. The rule endangers the pension system, ${ }^{204}$ its current members, ${ }^{205}$ future members, ${ }^{206}$ Kansas schools, ${ }^{207}$ and Kansas taxpayers. ${ }^{208}$ Perhaps most frightening, it manages to do all of this under the guise of protecting the integrity of the system. In order to truly protect the integrity of the system - one of the key policy purposes for adopting the California Rule - the Kansas Supreme Court must allow prospective modifications to pension plans. The alternative is to jeopardize KPERS members' futures, letting them rely on a pension fund that may go bankrupt before contributing members see a single benefit.

The abandonment of the California Rule would give the Kansas legislature the freedom necessary to properly address the pension deficit.

\footnotetext{
202. Id.

203. Singer v. City of Topeka, 607 P.2d 467, 474-77 (Kan. 1980).

204. In total, KPERS has a $\$ 9.5$ billion gap between state revenue and benefits owed to pension members. Shafroth, supra note 8 . The California Rule significantly limits Kansas's ability to address the pension deficit.

205. The underfunded KPERS plans endanger current members' future benefits. Conroy, supra note 3 , at 7 (noting Kansas's pension funding is below $60 \%$ of what will be due to future retirees).

206. See Farmer, supra note 142.

207. See Hanna, supra note 159 (noting that the expected KPERS shortfall should push the state to "move toward 401(k)-style plans for teachers").

208. Boehm, supra note 153 (describing how the possible failure of pension obligation bonds "can leave taxpayers on the hook for even more debt than they already were").
} 
The legislature would be able to modify pension plans without simultaneously being forced to add a comparable benefit. Therefore, modifications to reduce liabilities would not have to be accompanied by modifications that simply increase liabilities for a different aspect of the pension plan. For most states, a contribution increase of only $2.2 \%$ without the addition of comparable benefits - is capable of providing for retirees and resolving the average pension deficit within thirty years. ${ }^{209}$

Most importantly, KPERS members would still possess rights to all retroactive pension benefits. Section 74-4923(a) would continue to collectively prohibit detrimental retroactive modifications to employee benefits, which would firmly protect KPERS members' accrued pension benefits. This outcome is similar to a vast majority of pension plans across America, which operate under the Employee Retirement Income Act (ERISA). ${ }^{210}$ Similar to ERISA, which governs private pensions nationwide, the legislature would be strictly prohibited from altering any benefits a pension member has already earned but may make alterations affecting the rate at which future benefits are earned. ${ }^{211}$ As a result, the new precedent would realign Kansas pension law with generally accepted legal principles, provide the flexibility needed to remedy the pension deficit, and also provide reasonable and customary pension protection for KPERS members.

\section{CONCLUSION}

KPERS members and the citizens of Kansas deserve better than the California Rule. Abandoning the California Rule and only interpreting statutes as contracts when the legislature explicitly intends to be bound is a simplistic and honest resolution to the growing pension crisis. Rather than continue to promise benefits that Kansas is fiscally unable to deliver upon, the court must untie the legislature and permit pension modifications before the deficit affects the retirement plans of 289,000 Kansas employees.

209. Pension Funding Gaps, supra note 144, at 1.

210. Steven Malanga, How to Stop Courts' Blockades of Pension Reform, BloombergVIEW (Oct. 16, 2013, 6:14 PM), http://www.bloombergview.com/articles/2013-10-16/how-to-stop-courtsblockades-of-pension-reform.

211. Id. 